\title{
Experimental validation in Mediterranean shrub fuels of seven wildland fire rate of spread models.
}

\author{
Sauvagnargues S.*, Dusserre G.*, Lt-Colonel Robert F.**, \\ Dray G.***, Pearson D.W.***
}

* Ecole des Mines d'Alès - Laboratoire Génie d'Environnement Industriel

6, Avenue de Clavières - F 30319 ALES cedex - FRANCE

Tel: 0466782756 (S.S.) - 0466782752 (G.D.) - Fax: 0466782701

Email: gdusserr@ensm-ales.fr

** Service Département d'Incendie et de Secours de Lozère

3, rue des Ecoles - F 48000 MENDE - FRANCE

Tel: 0466656810 - Fax: 0466492701

*** Ecole des Mines d'Alès - Laboratoire Génie Informatique Ingénierie de Production

Parc Scientifique G. Besse - F 30000 NIMES - FRANCE

Tel: 0466387034 - Fax: 0466787074

Email: dray@eerie.fr ; pearson@eerie.fr 


\begin{abstract}
Indexes of forest fire risk are broadcast throughout the summer months by the French Civil Defense Authority. They are used to guide the deployment of fire prevention resources.

However, in some departments, the number of fires during the Winter and Spring months of March-April is equal or greater than during the Summer months. Some days, conditions are favourable for the propagation of fire (soil moisture content, vegetation in dormancy, relative humidity, ...), but indexes for estimating the risk during this period are not calculated.
\end{abstract}

The objective of this paper is to evaluate various models of fire rate of spread, in order to choose one for Winter and Spring fires. The Fire Service of a department of the French Mediterranean area (the Lozère department) provides the opportunity and the means to conduct validation experiments on prescribed fires. Also, validation data from another department of the French Mediterranean area (Pyrénées Orientales) are presented for the same rate of spread models.

\title{
Keywords
}

wildland fire - fire rate of spread models - precribed fire experiments - experimental validation 


\section{Introduction}

Since 1973, in the French Mediterranean area, the «Promethée » database has collected data on every fire: location, fire area, cause, etc ... (Stephan, 1995).

It shows that in some departments, the number of fires during March-April is equal or greater than in summer (see Figure 1). Some days, conditions are favourable for the propagation of fire (soil moisture content, vegetation in dormancy, relative humidity, ...), but indexes for estimating the risk during this period are not calculated.

These indexes of forest fire risk are broadcast by the Civil Defense Authority, but only in summer for most of them. They allow the deployment of fire prevention resources. Some of the indexes predict fire occurrence risk, others predict fire occurrence and propagation risk, and last, some predict only fire propagation (Sol, 1995).

The objective of this paper is to evaluate various models of fire rate of spread, in order to choose one for Winter and Spring fires (between January and April). The Fire Service of a department of the French Mediterranean area (the Lozère department) provides the opportunity and the means to conduct validation experiments on prescribed fires. Also, validation data from another department of the French Mediterranean area (Pyrénées Orientales) are presented for the same rate of spread models.

In the French Mediterranean area, prescribed fires are used to reduce fuels and to provide training opportunities for fire crews. They are also a way of managing forests 
and pasture. The prescribed fire campaign takes place each year from December to May, burning about 3600 ha/year (Gaulier, 1995).

The index of forest fire Winter risk that gives the best results will be included in a Geographical Information System. In the French Mediterranean area, most of the Fire Services have a G.I.S. for specific applications (maps, decision-making tools, ...). The index will be chosen on the basis of its efficiency for predicting the spread rate of Winter and Spring fires, and the facility for estimating the input data. It will give a numerical value of the rate of spread.

\section{Material and method}

The behavior of forest and brush fires is affected by several parameters that can be easily measured (Trabaud, 1979) (Chandler and al., 1983) (Trabaud, 1992) (Rothermel, 1983), particularly meteorological parameters, topographical parameters, and vegetation parameters.

French INRA (Institut National de la Recherche Agronomique) methods were used for measuring these parameters, especially those concerning vegetation (Etienne et Legrand, 1994) (Rochas, 1994).

All the data and sampling were carried out on a plot area of $400 \mathrm{~m}^{2}$ (see Figure 2).

The procedure adopted, when arriving at a site is first of all a reconnaissance to locate a representative area for the experimental plot. The plot equipment and the meteorological station are installed and samples are taken to determine the various 
parameters. When the plot is ready to be burnt, the fire is initiated with an ignition line ten meters below the plot. Observations, photographs, and films are taken during the plot burning.

Four groups of parameters were recorded, as needed by the different models: plot description, fuel description, meteorological conditions during the experiments, and fire description (only rate of spread measured over twenty meters).

\section{Description of the experiments in the Lozère department}

The study began in 1995, covering two prescribed fire campaigns (1995-1996 and 19961997). A general program of all sites to be burnt is established in September for the Lozère Fire Service. In this programme, some sites are chosen for carrying out experiments, selected according to the following criteria :

\section{- location:}

The sites are located in the Cévennes mountain range (highest point at $1500 \mathrm{~m}$ ) characterised for the purposes of our experiments by acid soil substratum. Homogeneous topographical conditions are required on the plot. The plot arrangement is given in Figure 2.

\section{- vegetation:}

This must be mainly composed of Genista purgans, shrub species that is currently found in the shape of large continuous shrub fields, in the mountains in the French Mediterranean area and particularly in the departments concerned by Winter and Spring fires. The height of vegetation (between 50 and $200 \mathrm{~cm}$ ) must be homogeneous on the 
plot, and the coverage by vegetation must be extensive (equal or more than $80 \%$ of coverage), that is frequently observed.

\section{- ignition and burning conditions:}

The burning technique must be head fire, in order to simulate real forest fires. The ignition line is located 10 meters below the experimental plot.

The rate of spread is measured with stop-watches, determined as the twenty meters length of plot divided by time taken for fire to spread across the twenty meters plot.

\section{Data from the Pyrénées Orientales department}

This department is also concerned by problems with Winter and Spring fires (see Figure 3) and also performed an experimental study on Genista purgans from January to April, since 1987. A database has been constituted.

Data are taken from this database of 72 fires. 62 of these prescribed fires were taken into account for the purposes of our study, for their appropriateness to the following criteria:

- Methods used to collect data are almost the same (moisture content, micrometeorological conditions, etc ...)

- Data with head fire as burning technique are considered.

The experimental plots are located in the Pyrénées, another French Mediterranean mountain range also concerned by Winter and Spring fires. The elevation plots are between 1000 and 2200 meters. The height of vegetation is almost homogeneous on the 
plot. Vegetation covers a wider range of fuel coverage (between 30 and $90 \%$ ), compared to the Lozère fires.

\section{Fire behavior models}

Seven models of fire behavior were chosen for validation. They all give a numerical value of the rate of spread.

They are chosen for their scientific credibility, their appropriateness to the Mediterranean area (based on Mediterranean vegetation, used in Mediterranean area), and their appropriateness from an operational point of view.

The Canadian Forest Fire Behavior Prediction System: (Forêts Canada, 1992)

This is a subsystem of the Canadian Forest Fire Danger Rating System. It estimates the head fire spread rate for sixteen fuel types, covering most major boreal forest fuel types in Canada.

The Canadian Prediction System does not include "shrub field" fuel type. So, all of the sixteen fuels models were tested. The best fuel model results are taken into account. The fuel model S-2 (conifer logging slash) gives best results with the Lozère data.

The model takes into account vegetation (type and moisture content), meteorological conditions (wind), and topography (slope). The model is similar for many of the fuel types in the system, but the parameters estimates vary with fuel type.

$$
\mathrm{V}=\mathrm{a}^{*}\left[1-\mathrm{e}^{(-\mathrm{b} * \text { ISI })}\right]^{\mathrm{c}}
$$


where: $\quad V$ is the rate of spread $\left(\mathrm{m} \cdot \mathrm{min}^{-1}\right)$

ISI is the Initial Spread Index

$\mathrm{a}, \mathrm{b}$ and $\mathrm{c}$ are specific parameters for each fuel type.

Rothermel model: (Rothermel, 1972) (Rothermel, 1983)

This is a systematic prediction method for describing a flame front advancing. It is used for training fire officers. For this work, we used the BEHAVE software (Andrews, 1986), which is the computer version of the Rothermel model. There are fourteen fuel models (Albini, 1976) (Hough and Albini, 1978).

Fuel model 4 is used, chosen by the « NFFL Fuel Model Key (Rothermel, 1983), as a fire fighter would do in an operational situation. The choise is based upon observations : determination of the general vegetation type, estimate wich stratum of surface fuel is most likely to carry the spreading fire, etc...

The fuel model 4 corresponds to brush, about $6 \mathrm{ft}$, with heavy loading of dead woody fuel, and where live fuel moisture can have a significant effect on fire behavior.

The mathematical equation is:

$$
\mathrm{R}=\mathrm{Ip} /(\rho \mathrm{be} * \text { Qig) }
$$

where: $\quad R$ is the rate of spread $(\mathrm{m} / \mathrm{s})$

$I p$ is the propagating flux $\left(\mathrm{W} / \mathrm{m}^{2}\right)$

pbe is the effective bulk density $(\mathrm{kg} / \mathrm{m} 3)$

Qig is the heat of pre-ignition $(\mathrm{J} / \mathrm{kg})$ 
The Drouet model: (Drouet, 1972)

This model is available in Winter and Spring in the French Mediterranean area (Sol, 1995). It is based upon meteorological conditions (windspeed, temperature, and ground moisture index that is fixed at $45 \mathrm{~mm}$ in this period). It is calculated in Summer by Météo France and broadcast to the Fire Services since 1988.

$$
\mathrm{VP}=180 * \operatorname{Exp}\left(\mathrm{T}^{*} 0.06\right) * \operatorname{Tgh}[(100-\operatorname{Res}) / 150] *[1+2 *[0.8483+\mathrm{Tgh}(\mathrm{V} / 30-1.25)]]
$$

where: $\quad V P$ is the rate of spread $\left(\mathrm{m} \cdot \mathrm{h}^{-1}\right)$

$T$ is the temperature $\left({ }^{\circ} \mathrm{C}\right)$

$V$ is the average windspeed $\left(\mathrm{km} \cdot \mathrm{h}^{-1}\right)$

Res is the ground moisture index $(\mathrm{mm})$.

The first Trabaud model: (Trabaud, 1979)

This model is based on the average windspeed and the height of vegetation. It has been developed from observations on experimental fires in the French Mediterranean area. It doesn't take into account the topography (constant slope is assumed).

$$
\mathrm{VP}=0.066 \mathrm{Uv}^{0.439} \mathrm{H}^{0.345}
$$

where: $\quad V P$ is the rate of $\operatorname{spread}\left(\mathrm{cm} \cdot \mathrm{s}^{-1}\right)$

$U v$ is the average windspeed $\left(\mathrm{cm} \cdot \mathrm{s}^{-1}\right)$

$H$ is the vegetation height $(\mathrm{cm})$ 
The second Trabaud model: (Trabaud, 1979)

This is almost the same model, with the fuel moisture content integrated. It still doesn't take the slope into account.

$$
\mathrm{VP}=5.72 \mathrm{Uv}^{0.400} \mathrm{H}^{0.352} / \mathrm{Tev}^{1.12}
$$

where: $\quad V P$ is the rate of spread $\left(\mathrm{cm} \cdot \mathrm{s}^{-1}\right)$

$U v$ is the average windspeed $\left(\mathrm{cm} \cdot \mathrm{s}^{-1}\right)$

$H$ is the vegetation height $(\mathrm{cm})$

$T e v$ is the vegetation moisture content ( $\%$ of green matter)

\section{The Valabre model:}

This model is taught at the Firefighter Officers School of Valabre (France). It is a very simplistic model, used to give a general idea of the propagation of the fire. It is based simply upon Fire Officers observations of windspeed and rate of spread. It considers the rate of spread of the fire as $3 \%$ of the average windspeed.

F.LO.RA.C. model: (Sauvagnargues et al., 1997)

This «Fuzzy LOgic RAte of spread Computation» method consists of estimating cluster centres of a collection of input/output data, where each cluster centre is in essence a prototypical data point that exemplifies a characteristic behavior of the rate of spread (Chiu, 1994). Cluster estimation is used as the basis of an algorithm for identifying a fuzzy rate of spread model. It is a generic model whose parameters will be 
identified with the data used in this work to validate the rate of spread models (about one hundred prescribed burnings).

It takes into account slope, vegetation height, and meteorological conditions (temperature, relative humidity, average windspeed).

The cluster estimation gives the following equation:

$$
\mu_{i}=e^{-1.7778\left\|y-y_{i}\right\| 2}
$$

where: $\mu_{\mathrm{i}}$ is a measure of the potential of data point $y_{\mathrm{i}}$ to be a cluster centre

$\mathrm{y}$ is the new input data vector (centred and normalised)

$\mathrm{y}_{\mathrm{i}}$ is the data vector corresponding to the $i$ th centre

The rate of spread equation is then:

$$
\mathrm{Z}=\left({ }^{\mathrm{c}} \Sigma_{\mathrm{i}=1} \mu_{\mathrm{i}} \mathrm{Z}^{*}{ }_{\mathrm{i}}\right) /{ }^{\mathrm{c}} \Sigma_{\mathrm{i}=1} \mu_{\mathrm{i}}
$$

Where: $\quad \mathrm{Z}$ is the rate of spread (centred and normalised value) in $\mathrm{m} . \mathrm{h}^{-1}$ $\mathrm{Z}_{\mathrm{i}}$ is the value of the output center

\section{Method used to compare models}

The aim of this work is not a statistical analysis of the different models with classic tools, but it is a contribution to an evaluation of the general effectiveness of the models for the French Mediterranean area, in operational conditions. 
So, the statistical methods used to compare the different models are based on published studies comparing toxic gas dispersion models (Hannah and al., 1991). They give the model performance measures, overpredictions and underpredictions.

Three methods are used in this study:

- Validation with the average ratio Xp/Xo (predicted values / observed values). This gives a quantitative evaluation of overprediction or underprediction (Spiegel, 1990).

- Validation with the calculation of the fractional bias (FB) (Equation 1) and the normalised mean square error (NMSE) (Equation 2) (Hannah and al., 1991). The NMSE gives an order of the variability of the model and the FB gives an order of the overprediction or underprediction vs observations. The range of the fractional bias statistic is $-2 \leq \mathrm{FB} \leq 2$, and the statistic is asymptotic for $\mathrm{Xp}$ and $\mathrm{Xo}$ equal to 0 . This could be used to provide a graphical representation of the model performance measures, but the linear trend between MG (Equation 3) and VG (Equation 4) is taken into account.

An optimum model gives $\mathrm{NMSE}=0$ and $\mathrm{FB}=0$.

$$
\begin{array}{ll}
\mathrm{FB}=\overline{(\mathrm{X}} \mathrm{o}-\overline{\mathrm{X}} \mathrm{p}) /\left[0.5^{*}(\mathrm{X} \mathrm{o}+\overline{\mathrm{X}} \mathrm{p})\right] & \text { Equation } 1 \\
\mathrm{NMSE}=\overline{(\mathrm{Xo}-\mathrm{X} \mathrm{p}})^{2} / \overline{\mathrm{X}}_{\mathrm{o}} * \overline{\mathrm{X} p} & \text { Equation } 2
\end{array}
$$

- Validation with the calculation of the geometric mean bias (MG) (Equation 3) and the geometric variance (VG) (Equation 4). The linear trend between the MG and the VG gives an order of the different models. An optimum model produces $M G=1$ and 
$\mathrm{VG}=1$. It is possible to provide a graphical representation of the model performance measures (Mohan, 1995).

$$
\begin{array}{ll}
\mathrm{MG}=\exp (\overline{\ln \mathrm{X}}-\overline{\ln \mathrm{X}} \mathrm{p}) & \text { Equation } 3 \\
\mathrm{VG}=\exp \left[\overline{\left.(\overline{\ln \mathrm{Xo}-\ln \mathrm{Xp}})^{2}\right]}\right. & \text { Equation } 4
\end{array}
$$

\section{Results}

\section{Experimental validation with the Lozère data}

Due to bad meteorological conditions during the two campaigns of prescribed fires only nine experiments were carried out since 1995 . They were all conducted between January and April.

\section{- Plots description and fuel characteristics}

The general description of plots and fuel characteristics are presented in Table 1.

The different values of the live fuel moisture content are almost homogeneous while the values of the dead fuel moisture content are more variable (from 18,5 to $6 \%$ ). The dead fuel moisture content seems to be correlated with the relative humidity $\left(r^{2}=0.81\right)$ in these experiments. This corrrelation is the basis for several different fire danger systems (Van Wagner, 1976)

\section{- Meteorological conditions}


The meteorological conditions are presented in Table 2.

The experiments took place in varying meteorological conditions: there are representative Winter conditions (PrT) and spring conditions (ViB and PrM). All the data were collected nearest to the ignition line of the fire, upwind to the fire.

\section{- Rates of spread}

Observed and predicted rates of spread are presented in Table 3.

The rate of spread of the Pre- 1 experiment is $0 \mathrm{~m} \cdot \mathrm{h}^{-1}$. For this experiment, ignition was impossible, probably because of the meteorological conditions of the day and also of the past days (many clouds and rain). The Pre-2 experiment took place in the same location, the same day. Differences come from meteorological conditions: Pre-1 was very cloudy, the temperature during Pre-2 was higher and it was a little later in the day.

\section{- Models evaluation on Lozère data}

The results of the models evaluation is presented on Table 4, based on the indexes defined previously. A preliminary general remark is that all models provide excellent results.

The BEHAVE software presents the highest ratio Xp/Xo (2.9), with the Valabre model (1.092). However, the overestimation the Valabre model shows is slight.

The five other models underestimate the propagation of the fire, with this data.

The FB index confirms these results, but only FLORAC has a fractional bias value close to zero (others are near to 1 ). 
According to NMSE, BEHAVE has the highest value, and the Trabaud (2) model produces greater variability in prediction than Trabaud (1) (1.064 v. 0.894).

The MG and VG indexes are more discriminant. A representation of the results is given in Figure 4.

FLORAC software gives excellent results, according to the representation. This may be explained by the fact that this model is partly developed from these data, and it has to be tested on wildland fires to improve its real efficiency.

The very simplistic Valabre model gives almost as good results as the Canadian FBPS on these data.

\section{$\underline{\text { Experimental validation with Pyrénées-Orientales data }}$}

The results of 62 experiments in the Pyrénées-Orientales department are presented here.

\section{- Plot description and fuel characteristics}

Plots are located in the Pyrénées mountains. The elevation is higher than in Lozère experiments. The same vegetation (Genista purgans) was present for the experiments. It has almost the same characteristics as in Lozère: height between 0.4 and 1.5 meters, coverage between $30 \%$ and $90 \%$.

\section{- Meteorological conditions}

Meteorological conditions measured during the experiments with a weather pack were highly variable. 
The temperature varies from $-5{ }^{\circ} \mathrm{C}$ to $16{ }^{\circ} \mathrm{C}$; windspeed varies from $15 \mathrm{~m} . \mathrm{s}^{-1}$ to $0 \mathrm{~m} . \mathrm{s}^{-1}$; relative humidity varies from $5 \%$ to $100 \%$.

\section{- Rates of spread}

The observed rate of spread during these experiments, for head fires only varies from 0 $\mathrm{m} / \mathrm{h}$ (impossible ignition because of the meteorological conditions) to $2000 \mathrm{~m} / \mathrm{h}$.

\section{- Model evaluation on Pyrénées-Orientales data}

The results of the models evaluation is presented in Table 5, based on the indexes defined previously.

The results of the model evaluation are different for the Pyrénées-Orientales data, compared to the Lozère data. Some results are similar, while others are completely different.

As for the Lozère experiments, BEHAVE overestimates according to the ratio $\mathrm{Xp} / \mathrm{Xo}$ (3.18). But in these experiments, FLORAC and the Canadian FBPS appear overstimating too, and the Canadian FBPS overestimates the most (3.35).

The fractional bias doesn't confirm these results.

According to FB, FLORAC and BEHAVE are the only models that overpredict values, and this is confirmed by the MG values.

These observations can be explained by the fact that the ratio $\mathrm{Xp} / \mathrm{Xo}$ is calculated upon few data taken in particular conditions (Winter and Spring fires), maybe near the limits of validity of the model. The models evaluation indexes show the model's efficiency in 
general. So it can be overpredicting on a particular sample but generally underpredicting.

The study of FB and NMSE values shows that the Drouet model and the two Trabaud models produce greater variability in prediction than the others, and largely underpredict.

The Canadian FBPS gives optimal results according to these indexes, but also with the MG / VG indexes. However, it is overestimating on these data set (ratio Xp/Xo = 3.35). These results and those of the Lozère experiments are similar.

FLORAC gives also excellent results according to all indexes. But as for Lozère experiments, it must be tested on wildland fires to improve its efficiency.

The MG and VG indexes give a representation of the results, shown in Figure 5.

Models are grouped into three groups:

1- Canadian FBPS and FLORAC give very good results, with a low geometric variance (VG), close to 1, indicating low scatter; and a low geometric mean bias (MG), also close to 1 , indicating a very slight underprediction.

2- BEHAVE and the Valabre model that give more underpredicting and variable results. 3- the position of the Drouet and the two Trabaud models indicates the largest underprediction and scattering results on these experiments. 


\section{Discussion}

The model performance measure on these two series of experiments doesn't give the same results, but the same classification is deduced. There are three models that give excellent results (Canadian FBPS, Valabre model, FLORAC), they are underpredicting or overpredicting, but always very slightly.

The difference in the results between the experiments can be explained by the fact that there is uncertainty in the methods used to collect the data (rate of spread measurements, meteorological data), and the experimental conditions might have been different.

However, this work shows that the model's efficiency is not related to the complexity: in these conditions, a very simple model (Valabre) can give as good results as a more complex one (Canadian FBPS, for example).

The performance evaluation of BEHAVE confirms the one made by Andrews that shows BEHAVE is close to reality on prescribed fires (Andrews, 1980).

These results can also be compared to those of McAlpine conducted in wind tunnel combustion facilities (McAlpine and Xanthopoulos, 1989). BEHAVE and the Canadian FBPS were compared. The conclusions were that BEHAVE tends to underpredict while the Canadian FBPS tends to overpredict. These result are confirmed for the Canadian FBPS and for BEHAVE according to the MG and VG indexes.

The choice of model depends upon its use. 
For prevention use (land management, prevention of forest fire), complex models giving good results and needing computed data (even complex data) may be used for simulating fire behavior and after simulation, positioning equipment in forests (roads, water-tank, ...). However, simple model can also be useful for prevention.

For fire fighting, conditions for the choice of a model must be its efficiency, short time for calculation, and the ease of estimating input data. A fire-fighter Officer must have a reliable estimation of the fire behavior very quickly, without spending a long time for estimating input data and for calculations. But, for particular situations (long-time fires for example) more complex models can be used with their user-oriented fields guide (BEHAVE or Canadian FBPS) available on Internet (/s=fire?/ou1=w02a@mhsfswa.attmail.com).

\section{Conclusion}

The aim of this work is to help to identify a fire behavior model for fighting Winter and Spring fires in the South of France. The choice is made with performance measures and the ease for estimating input data.

According to the results, the choice is made on the three models that give best results: Canadian FBPS, Valabre model, FLORAC.

Canadian FBPS can cause some problems in computing input data (McAlpine and Xanthopoulos, 1989), as, for example, obtaining values on litter moisture content.

The choice between Valabre model and FLORAC is difficult. The Valabre model gives excellent results and input data are easily estimated, but it only depends on one 
parameter. FLORAC is elaborated upon data coming from the countries concerned by specific Winter and Spring fire problems, but needs further experiments with a wide range of conditions to improve its efficiency on wildlands fires.

\section{Acknowledgements}

The assistance of the fire fighters of Lozère in helping to conduct the experiments is acknowledged with appreciation.

\section{Bibliography}

Albini F.A. 1976. Estimating wildfire behavior and effects. USDA Forest Serv. Intermountain Research Station, Gen. Tech. Report INT-30: 92 p.

Andrews P.L. 1980. Testing the fire behavior model. 6th Conference on Fire and Forest Meteorology Proceedings: 70-77.

Andrews P.L. 1986. BEHAVE: fire behavior prediction and fuel modeling systemBURN Subsystem, part 1. USDA Forest Serv. Intermountain Research Station, Gen. Tech. Report INT-194: 130 p.

Chandler C., Cheney P., Thomas P., Trabaud L., Williams D. 1983. Chemistry and Physics of Ignition and Combustion. Fire in Forestry. Wiley-Interscience, New-York: 412.

Chiu S.L. 1994. Fuzzy model identification based on cluster estimation. Journal of Intelligent and Fuzzy Systems, Vol 2, pp 267-278. 
Drouet J.C. 1972. Etude théorique de la lutte contre les feux de forêts. Thèse d'Etat. Université de Marseille-Provence.

Etienne M. and Legrand C. 1994. A non destructive method to estimate shrubland biomass and combustibility. Int. Conf. Forest Fire Research, Coimbra Proceedings. B.25: $425-434$.

Forêts Canada Groupe de travail sur les dangers d'incendie. 1992. Elaboration et structure de la méthode de prévision du comportement des incendies de forêt. Forêts Canada, direction générale des sciences et du développement durable, Rapport d'information ST-X-3F: 67 p.

Gaulier A. 1995. Guide de l'utilisateur de la Fiche Brûlage Dirigé - Réseau des équipes de Brûlage Dirigé. I.N.R.A. Avignon.

Hannah S. Strimaitis C. Chang J. 1991. Evaluation of foorteen hazardous gas models with ammonia and hydrogen fluoride field data. J. of Hazardous Materials, 26: 127-158. Hough W.A. Albini F.A. 1978. Predicting fire behavior in palmetto-gallberry fuel complexes. USDA Forest Serv. Southeastern Forest and Range Experiment Station, Research. Paper SE-174: 44 p.

McAlpine R.S. Xanthopoulos G. 1989. Predicted vs Observed fire spread rates in Ponderosa Pine fuel beds: a test of american and canadian systems. 10th Conference on Fire and Forest Meteorology, Ottawa Proceedings: 287-294.

Mohan M. Panwar T. S. Singh M. P. 1995. Development of dense gas dispersion model for emergency preparedness. Atmospheric Environment, 29: 2075-2087.

Richard B. 1995. Toward a new approach to forest fire. Nice Proc. Int. Emergency management and Engineering Conf., 1: 190-194. 
Rochas L. 1994. Inflammabilité et indice de siccité de la bruyère arborescente et de l'arbousier. I.N.R.A. Laboratoire de Recherches Forestières Méditerranéennes, Document PIF 9425.

Rothermel R.C. 1972. A mathematical model for predicting fire spread in wildland fuels. USDA Forest Serv. Intermountain Forest and Range Experiment Station, Res. Pap. INT-115: 40 p.

Rothermel R.C. 1983. How to predict the spread and intensity of forest and range fires. USDA Forest Serv. Intermountain Forest and Range Experiment Station, Gen. Tech. Report INT-143: 159 p.

Sol B. 1995. Comparaison de diverses méthodes d'estimation du danger météorologique d'incendie sur le Sud-Est de la France. Météo-France Direction Interrégionale Sud-Est, Note DIR/SE N¹3: 25 p.

Sauvagnargues S. Dusserre G. Dray G. Peton N. Pearson D.W. 1997. Determination of a wildland fire rate of spread model using fuzzy logic. International Symposia on Intelligent Industrial Automation and Soft Computing, Nîmes Proceedings: 69-73.

Spiegel M.R. 1990. Théorie et applications de la statistique. Série Schaum, Edition McGraw-Hill, Paris: 358 p.

Stephan J..M. 1995. L'organisation des banques de données relatives aux feux de forêts en France. Options Méditerranéennes, Série A, 25: 67-71.

Trabaud L. 1979. Etude du comportement du feu dans la Garrigue de Chêne kermes à partir des températures et des vitesses de propagation. Ann. Sci. forest., 36: 13-38. Trabaud L. 1992. Les principes de combustion. Les feux de Forêts, mécanismes, comportement et environnement. France Sélection, Aubervilliers: 43-79. 
Van Wagner C.E. 1976. Structure de l'indice canadien forêts-météo. Ministère de l'Environnement Service canadien des forêts, publication $n^{\circ} 1333 \mathrm{~F}$ : 44p. 


\section{TABLES AND FIGURES}

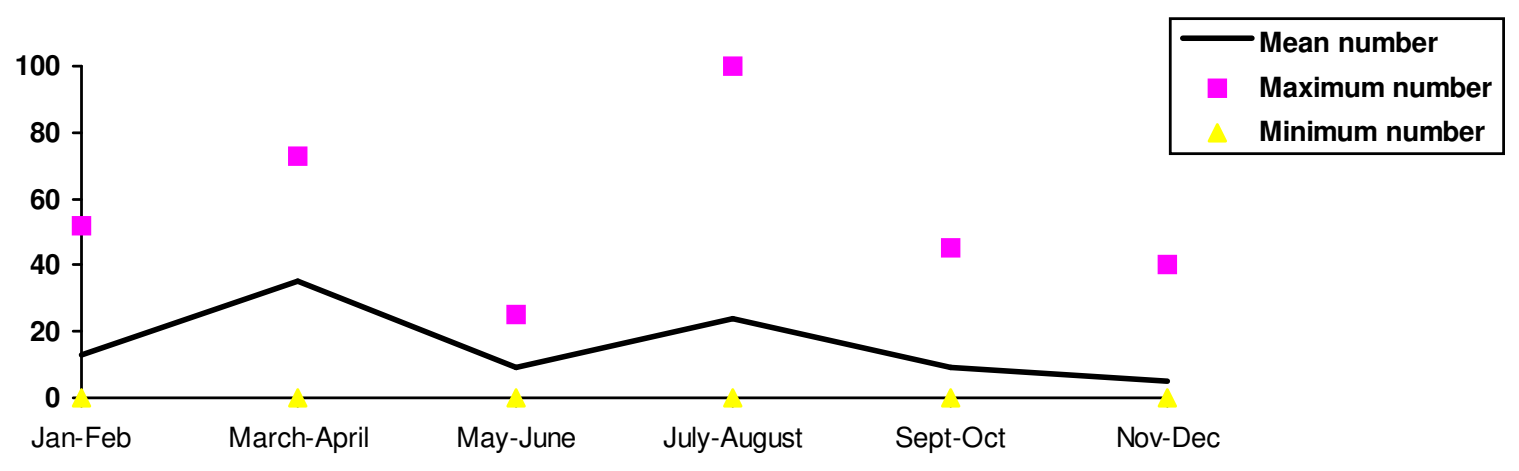

Figure 1: Number of fire during all year in the Lozère department since 1973.

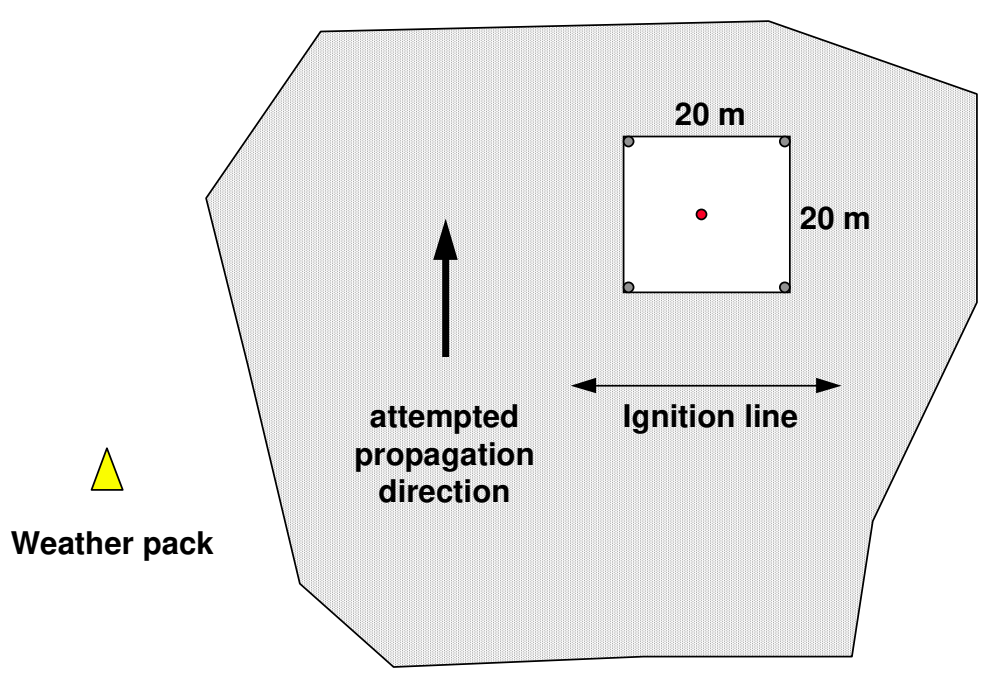

Figure 2: The experimental plot. 


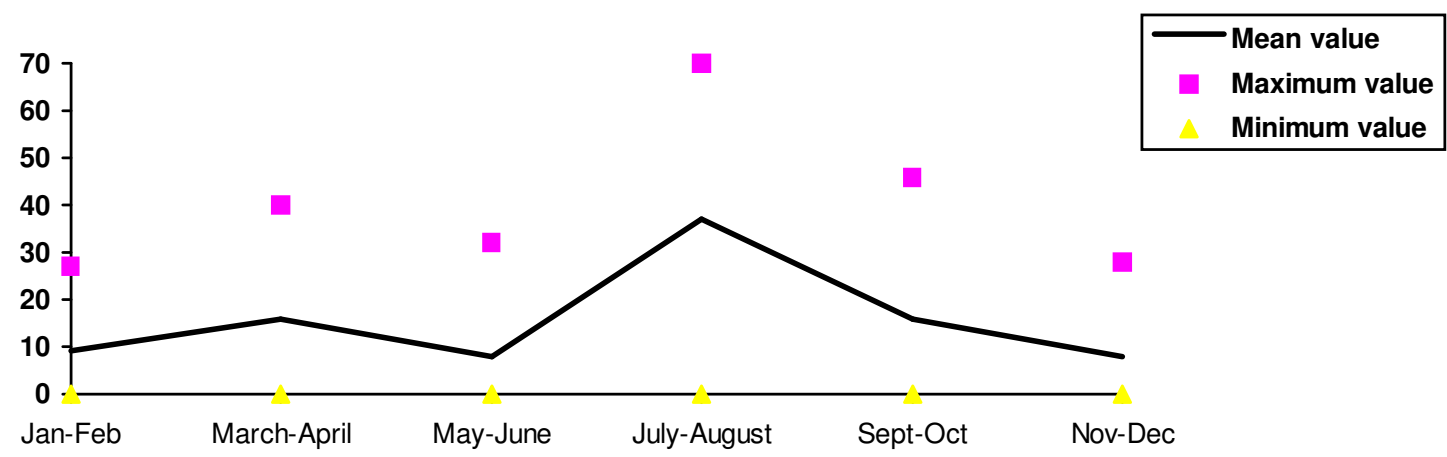

Figure 3: Number of fire during all year in the Pyrénés Orientales department since 1973.

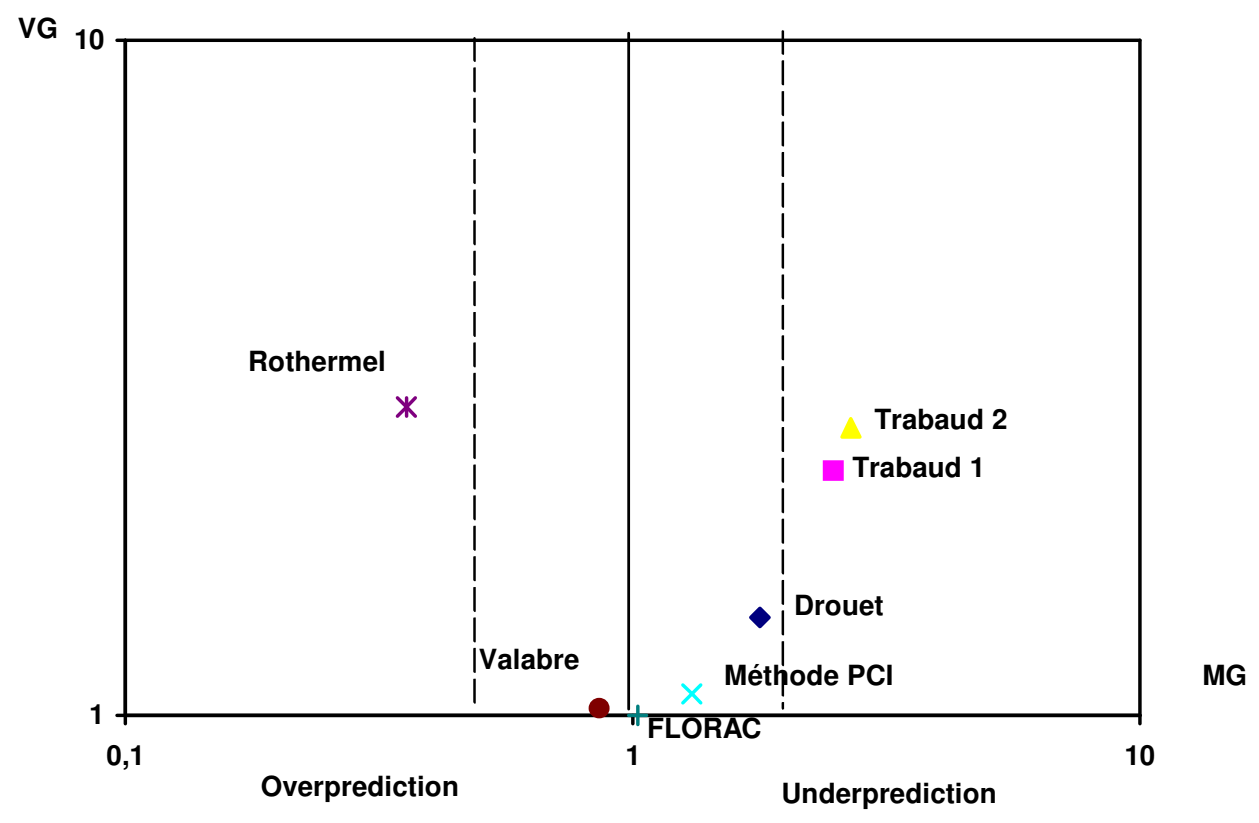

Figure 4: Models performance measure, based on the representation of VG and MG indexes (Lozère experiments). 


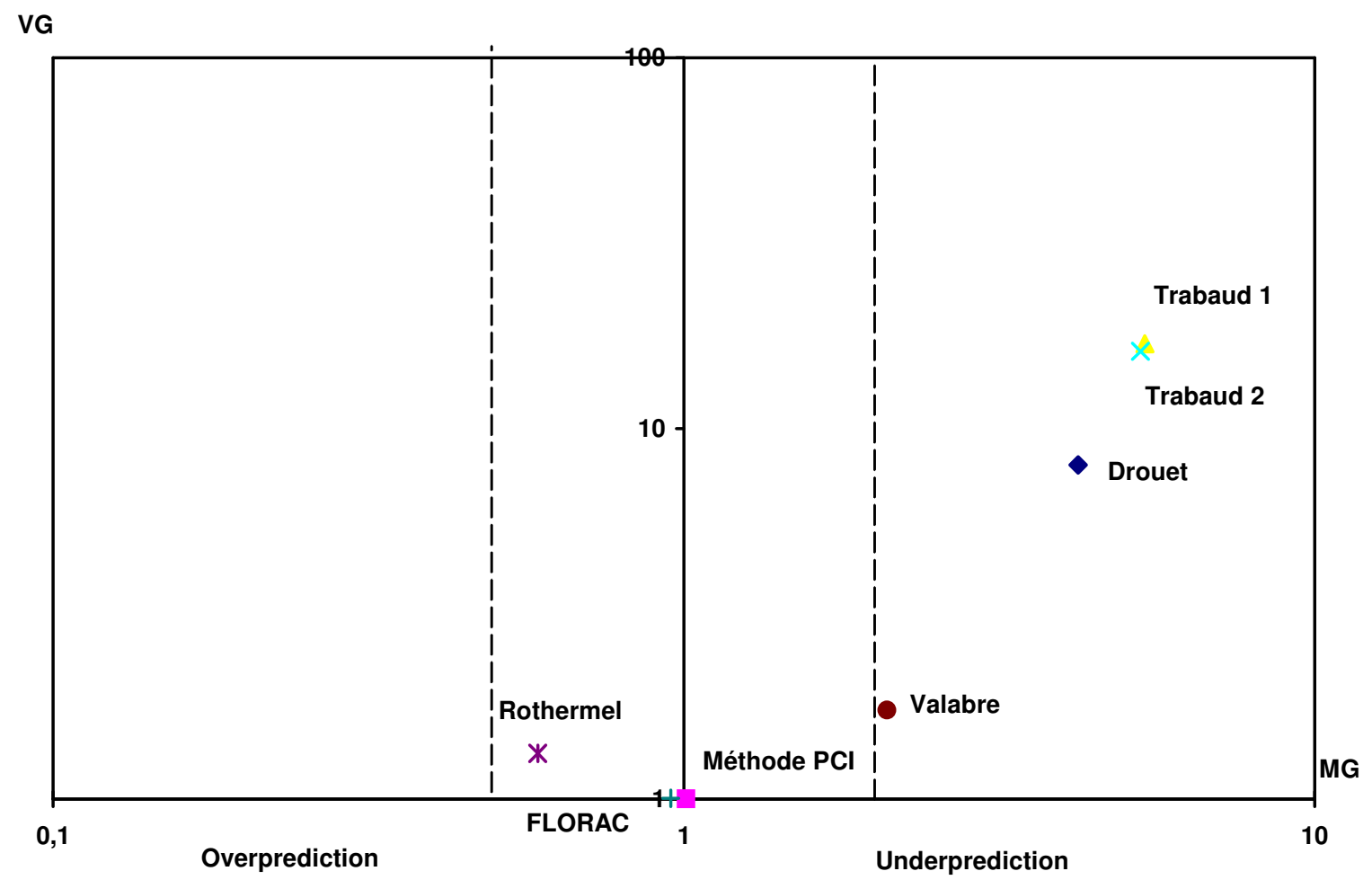

Figure 5: Models performance measure, based on the representation of VG and MG indexes (Pyrénés Orientales experiments).

\begin{tabular}{|c|c|c|c|c|c|c|c|c|c|}
\hline $\begin{array}{l}\text { Names of the } \\
\text { experiments }\end{array}$ & StJ & PrR & PrT & ViB & Pre-1 & Pre-2 & Po & Rou & PrM \\
\hline \multicolumn{10}{|c|}{ Plots description } \\
\hline Elevation $(\mathrm{m})$ & 760 & 1035 & 1016 & 775 & 690 & 690 & 815 & 1270 & 1035 \\
\hline Slope $(\%)$ & 40 & 25 & 20 & 10 & 40 & 40 & 25 & 10 & 30 \\
\hline Aspect & $\mathrm{N} \mathrm{NW}$ & $\mathrm{E}$ & NW & S SE & W SW & W SW & W & SW & $\mathrm{E}$ \\
\hline \multicolumn{10}{|c|}{ Fuel charasteristics } \\
\hline Height $(\mathrm{cm})$ & 200 & 50 & 50 & 70 & 150 & 150 & 130 & 120 & 80 \\
\hline $\begin{array}{l}\text { Live fuel moisture } \\
\text { content }(\%)\end{array}$ & 57.8 & 49.7 & 49.9 & 46.5 & 53 & 53 & 48.1 & 49.5 & 50.7 \\
\hline $\begin{array}{l}\text { Dead fuel (on } \\
\text { foot) moisture } \\
\text { content }(\%)\end{array}$ & 15.4 & 13.2 & 10.6 & 6 & 18.5 & 18.5 & 11.1 & 13.9 & 8.3 \\
\hline $\begin{array}{l}\text { Litter moisture } \\
\text { content }(\%)\end{array}$ & $\begin{array}{c}\text { non } \\
\text { measured }\end{array}$ & 38 & 26 & 33 & 28.2 & 28.2 & 31.1 & 53.6 & 26.6 \\
\hline
\end{tabular}

Table 1: General description of plots and fuels 


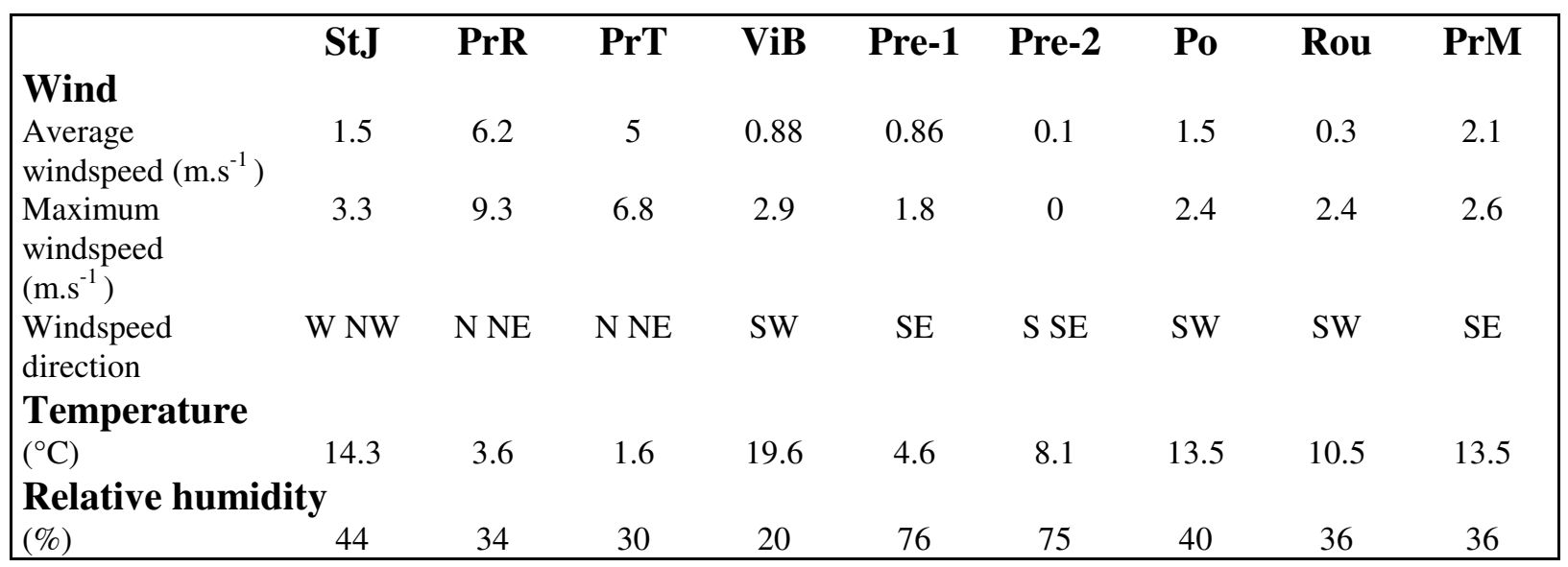

Table 2: meteorological conditions during Lozère experiments

\begin{tabular}{|c|c|c|c|c|c|c|c|c|c|}
\hline & StJ & PrR & PrT & ViB & Pre-1 & Pre-2 & Po & Rou & PrM \\
\hline \multicolumn{10}{|c|}{ Observed rate of spread } \\
\hline$\left(\mathrm{m} \cdot \mathrm{h}^{-1}\right)$ & 90 & 150 & 600 & 235 & 0 & 240 & 218 & 50 & 360 \\
\hline \multicolumn{10}{|c|}{ Predicted rate of spread } \\
\hline $\begin{array}{l}\text { BEHAVE (FM 4) } \\
\left(\mathrm{m}^{-1} \mathrm{~h}^{-1}\right)\end{array}$ & 360 & 1220 & 2160 & 260 & 140 & 300 & 360 & 100 & 520 \\
\hline $\begin{array}{l}\text { Canadian FBPS } \\
(\mathrm{S}-2)\left(\mathrm{m} \cdot \mathrm{h}^{-1}\right)\end{array}$ & 37 & 69 & 212 & 81 & 309 & 296 & 139 & 309 & 327 \\
\hline $\begin{array}{l}\text { Drouet model } \\
\left(\mathrm{m} \cdot \mathrm{h}^{-1}\right) \\
\end{array}$ & 167 & 138 & 108 & 218 & 89 & 103 & 159 & 121 & 167 \\
\hline model $\left(\mathrm{m}^{-\mathrm{h}^{-1}}\right)$ & 144 & 144 & 144 & 72 & 108 & 36 & 108 & 72 & 108 \\
\hline $\begin{array}{l}\text { Trabaud (2) } \\
\text { model }\left(\mathrm{m}^{-1} \mathrm{H}^{-}\right)\end{array}$ & 108 & 144 & 108 & 72 & 72 & 36 & 108 & 72 & 108 \\
\hline $\begin{array}{l}\text { Valabre model } \\
\left(\mathrm{m}^{-\mathrm{h}^{-1}}\right) \\
\text { FLORAC }\end{array}$ & 162 & 670 & 540 & 95 & 93 & 11 & 162 & 32 & 227 \\
\hline$\left(\mathrm{m} \cdot \mathrm{h}^{-1}\right)$ & 89 & 150 & 600 & 235 & 238 & 57 & 263 & 26 & 242 \\
\hline
\end{tabular}

Table 3: Observed and predicted rate of spread during Lozère experiments. 


\begin{tabular}{|l|c|c|c|c|c|}
\cline { 2 - 6 } \multicolumn{1}{c|}{} & $\begin{array}{c}\text { Predicted } \\
\text { Observed }\end{array}$ & FB & NMSE & MG & VG \\
\hline Drouet model & 0.902 & 0.563 & 0.344 & 1.783 & 1.397 \\
\hline Trabaud (1) model & 0.62 & 0.855 & 0.894 & 2.493 & 2.303 \\
\hline Trabaud (2) model & 0.576 & 0.917 & 1.064 & 2.692 & 2.667 \\
\hline Canadian FBPS (S-2) & 0.665 & 0.269 & 0.074 & 1.311 & 1.076 \\
\hline BEHAVE (FM 4) & 2.9 & -0.944 & 1.148 & 0.358 & 2.865 \\
\hline Valabre model & 1.092 & -0.15 & 0.023 & 0.86 & 1.023 \\
\hline FLORAC & 0.82 & 0.022 & 0 & 1.023 & 1 \\
\hline
\end{tabular}

Table 4: Model evaluation results for Lozère experiments.

\begin{tabular}{|l|c|c|c|c|c|}
\cline { 2 - 6 } \multicolumn{1}{c|}{} & $\begin{array}{c}\text { Predicted } \\
\text { Observed }\end{array}$ & FB & NMSE & MG & VG \\
\hline Drouet model & 0.636 & 1.234 & 2.459 & 4.222 & 7.961 \\
\hline Trabaud (1) model & 0.519 & 1.313 & 3.564 & 5.378 & 16.949 \\
\hline Trabaud (2) model & 0.514 & 1.365 & 3.491 & 5.302 & 16.164 \\
\hline Canadian FBPS (S-2) & 3.35 & 0.01 & 0 & 1.01 & 1 \\
\hline BEHAVE (FM 4) & 3.18 & -0.521 & 0.291 & 0.587 & 1.329 \\
\hline Valabre model & 0.996 & 0.736 & 0.627 & 2.165 & 1.816 \\
\hline FLORAC & 1.67 & -0.047 & 0.002 & 0.954 & 1.002 \\
\hline
\end{tabular}

Table 5: Model evaluation results for Pyrénés Orientales experiments. 